\title{
Vegetation composition differentiation and species-environment relationships in the northern part of Isfahan Province, Iran
}

\author{
Hadi KARGAR-CHIGANI ${ }^{1}$, Seyed Akbar JAVADI ${ }^{1 *}$, Ghavamodin ZAHEDI-AMIRI ${ }^{2}$, Seyed \\ Jamaleddin KHAJEDDIN ${ }^{3}$, Mohamad JAFARI ${ }^{2}$ \\ ${ }^{1}$ Department of Range Management, Science and Research Branch, Islamic Azad University, Tehran 1477893855, Iran; \\ ${ }^{2}$ Faculty of Natural Resources, University of Tehran, Karaj 315854314, Iran; \\ ${ }^{3}$ Range and Watershed Management Division, Department of Natural Resources, Isfahan University of Technology, Isfahan \\ 8415683111, Iran
}

\begin{abstract}
A considerable proportion of Iran's territory is covered with arid and semi-arid rangelands and mismanagement and overexploitation of those rangelands have resulted in serious ecological degradation. Thus, the need is pressing to examine the present species composition and the relationships with environmental factors for providing the needed scientific references to species conservation and ecological rehabilitation efforts. The aims of this study were to examine the species composition and to delineate the most important factors influencing the distributions of plant species and groups in the northern rangelands of Isfahan Province (Iran) using two-way indicator species analysis (TWINSPAN), detrended correspondence analysis (DCA), principal component analysis (PCA), and canonical correspondence analysis (CCA). Field investigations were conducted in the growing season of 2014 using stratified random method in 22 homogeneous sampling units. In total, 75 plant species belonging to 52 genera and 19 families were identified. The most important families were Asteraceae and Papilionaceae, the most important genera were Astragalus, Cousinia, and Acanthophyllum, and the most important species were Artemisia aucheri and Artemisia sieberi. Plant species were classified into 10 groups using TWINSPAN. DCA was used to estimate the magnitude of changes in species composition along the first two ordination axes to provide gradient length estimations for PCA and CCA ordinations. The first three PCA axes and the first three CCA axes demonstrated similar cumulative percentage of variance, indicating that the environmental factors (selected by PCA) used in CCA ordination were acceptable for explaining the species composition and the distributions. CCA ordination showed that the first axis was closely related to elevation, slope, surface bare soil cover, surface litter cover, gravel proportion, organic matter, total nitrogen, $\mathrm{CaCO}_{3}$ content, and grazing intensity and that the second axis was closely related to sand proportion, silt proportion, clay proportion, and saturation percentage. Among these factors, elevation was the most effective factor to separate the plant groups and grazing was the major cause of rangeland degradation.
\end{abstract}

Keywords: rangeland; classification; ordination; multivariate analysis; plant groups; Isfahan Province

Citation: Hadi KARGAR-CHIGANI, Seyed Akbar JAVADI, Ghavamodin ZAHEDI-AMIRI, Seyed Jamaleddin KHAJEDDIN, Mohamad JAFARI. 2017. Vegetation composition differentiation and species-environment relationships in the northern part of Isfahan Province, Iran. Journal of Arid Land, 9(2): 161-175. doi: 10.1007/s40333-017-0050-2

\section{Introduction}

As the most important component in natural ecosystems, plant communities vary greatly at regional scales (Nimis, 1985). As an indicative expression of a plant community, species

*Corresponding author: Seyed Akbar JAVADI (E-mail: a.javadi@srbiau.ac.ir)

Received 2015-08-19; revised 2016-01-12; accepted 2016-08-03

(C) Xinjiang Institute of Ecology and Geography, Chinese Academy of Sciences, Science Press and Springer-Verlag Berlin Heidelberg 2017 
composition is mainly controlled by environmental factors such as topography, soil, and climate at regional scales (Escudero et al., 2000; Amezaga et al., 2004). It was early noted that soil can be one of the most important factors affecting the species composition because it is not only the substrate of plant growth but also the product of climate, biology, topography and time (Jenny, 1980). It should be particularly pointed out that with increasing intensities of human activities (e.g., grazing), human-induced environmental change has significantly influenced the species composition at regional scales (Bai et al., 2001; Amezaga et al., 2004). At short-time scales, the dominant factors influencing the species composition may differ significantly from a region to another region and from an ecosystem to another ecosystem (He et al., 2007; Xu et al., 2011). At long-time scales, species composition could in turn influence soil properties and even the micro-climate (El-Ghani and Amer, 2003; Enright et al., 2005). Thus, analysis of species-environment relationships is always at the center of biogeographic studies (He et al., 2007).

Multivariate analysis methods were often used to quantitatively and qualitatively analyze the species composition and the relationships with environmental factors (Villers-Ruiz et al., 2003; Kargar Chigani et al., 2012). Among these methods, classification and ordination techniques are among the most widely employed (Van de Ven et al., 2007). These techniques include two-way indicator species analysis (TWINSPAN; Jafari et al., 2004; He et al., 2007), principal component analysis (PCA; Salehi and Amiri, 2005; Koull and Chehma, 2015), detrended correspondence analysis (DCA; Hill and Gauch, 1980; Corney et al., 2006; He et al., 2007; Salehi et al., 2007; Jeloudar et al., 2010), and canonical correspondence analysis (CCA; Sang, 2009; Zuo et al., 2014; Koull and Chehma, 2016). There are numerous cases of successfully employing these techniques. For example, He et al. (2007) employed TWINSPAN, DCA, and CCA to study the environmental factors influencing the species composition in the Alxa Plateau of China and found that soil organic matter, soil total nitrogen, soil texture, elevation, and relative humidity were the most important factors. Zuo et al. (2014) used CCA to examine the relationships between plant species richness and environmental factors in northern China and found that plant species richness was significantly correlated with soil properties and elevation.

In Iran, a considerable proportion of the country's territory is covered with arid and semi-arid rangelands and mismanagement and overexploitation of those rangelands have resulted in serious ecological degradation, especially in the northern part of Isfahan Province. Thus, the need is pressing to examine the present species composition and the relationships with environmental factors. The main objectives of this study were to analyze the species composition and to delineate the species-environment relationships in the northern rangelands of Isfahan Province using classification and ordination techniques. It is our hope that this study may provide the needed scientific references to species conservation and ecological rehabilitation efforts for the study area and also for other similar areas.

\section{Materials and methods}

\subsection{Study area}

This study was conducted in the Meymeh region, the northern part of Isfahan Province, Central Iran $\left(33^{\circ} 22^{\prime}-33^{\circ} 38^{\prime} \mathrm{N}, 51^{\circ} 10^{\prime}-51^{\circ} 31^{\prime} \mathrm{E}\right.$; $2004-3157 \mathrm{~m}$ a.s.l.; Fig. 1). The study area occupies an area of approximately $61.6 \mathrm{~km}^{2}$ and has an average slope of $16 \%$. The mean annual precipitation is about $177 \mathrm{~mm}$ and the mean annual temperature is about $12^{\circ} \mathrm{C}$. Based on the data from the adjacent meteorological stations, the climates in the study area and the adjacent areas are strongly topography-dependent. Steppe species dominate the area that is mainly underlain by the geological units of the Neogene and Quaternary periods.

\subsection{Sampling}

Stratified random sampling method (Mueller-Dombois and Ellenberg, 1974; Ludwig and Reynold, 1988) was used in this study. Digital elevation model (10 m of pixel size) was produced using ArcGIS 10.0 software, and topographic maps (i.e., slope, aspect, and elevation) were 


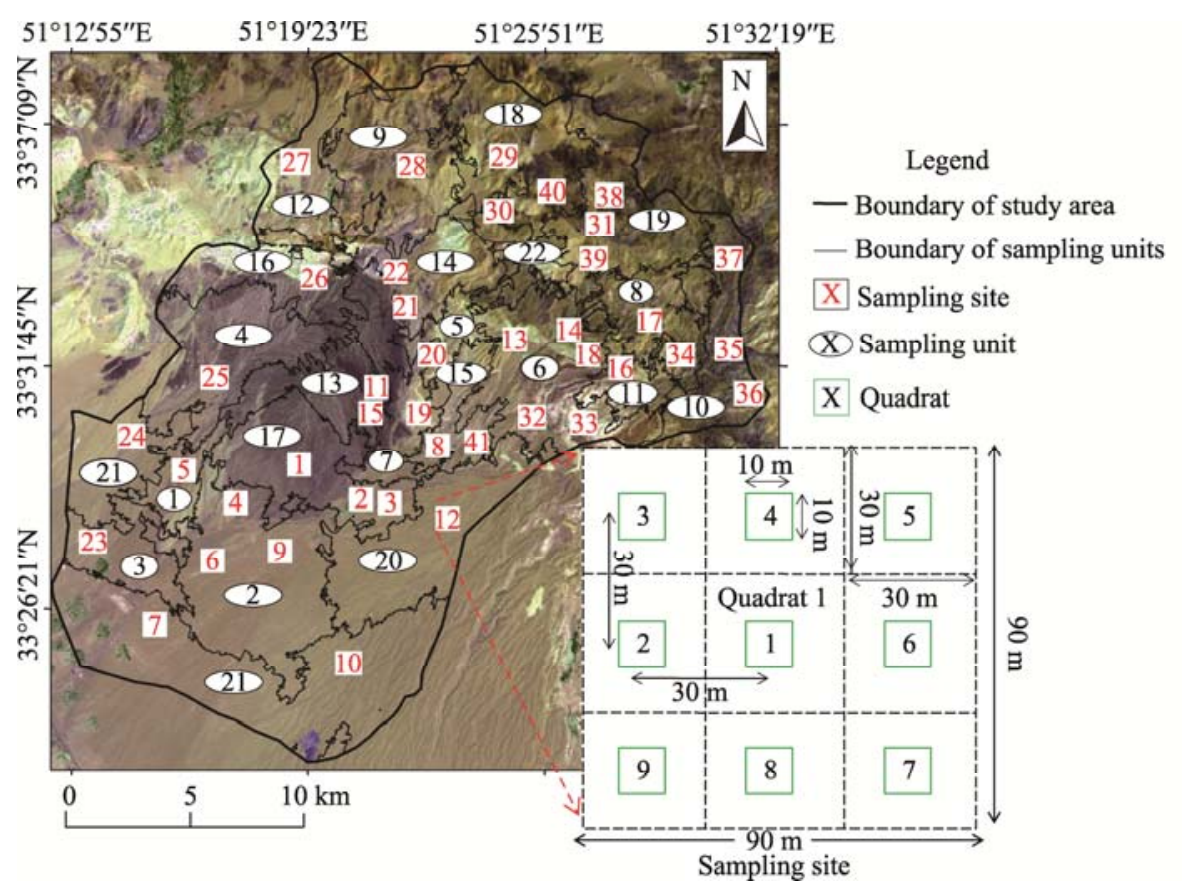

Fig. 1 Locations of the sampling units and sampling sites

subsequently generated. We divided the study area into 22 homogeneous sampling units based on those topographic maps (i.e., slope, aspect, and elevation maps) and the geological map (see Fig. 1). Each sampling unit was unique in terms of vegetation and soil types. Then, we investigated the key regions of each sampling unit in the field survey and identified 41 sampling sites (1-4 sites per sampling unit) according to vegetation and soil types (Mueller-Dombois and Ellenberg, 1974). The field survey was carried out in the growing season of 2014 (i.e., from mid-May to mid-July).

In each sampling site, 9 quadrats with a distance of $30 \mathrm{~m}$ from each other and 3 random soil profiles were selected according to the variations of vegetation and environmental factors (e.g., slope, aspect, elevation, etc.). Totally, 369 quadrats were selected and the average size of each quadrat was $100 \mathrm{~m}^{2}(10 \mathrm{~m} \times 10 \mathrm{~m})$. For each quadrat, plant species, density, frequency, canopy cover, surface litter cover, surface stone cover, surface pebbles cover, and surface bare soil cover were identified or determined. Furthermore, the latitude, longitude, and altitude of each quadrat were recorded using a GPS receiver, and the slope and aspect of each quadrat were recorded using a Brunton compass.

Two soil samples from each soil profile were obtained at the depths of 0-30 and 30-60 cm and totally 246 soil samples were collected. The soil samples were air-dried and sieved through a $2-\mathrm{mm}$ sieve for analyzing the physical and chemical properties. Electric conductivity (EC) and $\mathrm{pH}$ were determined using a conductivity meter (JENWAY 4310) and a glass electrode pH-meter (Metrohm 744), respectively. Particle size was determined using the hydrometer method (Bouyoucos, 1962). Bulk density was measured using the method described by Berigari and Al-Any (1994). Porosity was calculated using the following equation: soil porosity $=100$-(soil bulk density/2.65×100). Saturation percentage was measured by weighing method and $\mathrm{CaCO}_{3}$ content was measured by titration with $\mathrm{NaOH}$. Organic matter was measured using the method of Black (1965) and total nitrogen was measured using Kjeldahl method (Bremner and Mulvaney, 1982).

\subsection{Grazing intensity}

Based on the criteria developed by Holechek et al. (1998), we classified the grazing intensity in the study area into three categories (i.e., heavy, moderate, and light) and calculated the grazing pressure to quantify the values of grazing intensity. Grazing pressure is the ratio of available 
livestock (or forage demand) to the allowable livestock (or stocking rate). According to the social conventions, the rangelands within the study area are divided into 22 grazing allotments by local herders. Grazing pressure of each grazing allotment was calculated through the following four steps. First, the average forage production $\left(\mathrm{kg} / \mathrm{hm}^{2}\right)$ in each grazing allotment was determined using clipping and weighing method (Van Dyne et al., 1963) at the beginning of the grazing season (i.e., from late-April to mid-May). Second, the allowable livestock (or stocking rate) was calculated by dividing the total available forage $\left(\mathrm{kg} / \mathrm{hm}^{2}\right)$ with the forage demand $(\mathrm{kg})$. Third, the number of available livestock in each grazing allotment was recorded by counting the number of livestock in each herd during the grazing season (i.e., from mid-May to mid-September). Fourth, grazing pressure of each grazing allotment was calculated by dividing the available livestock with the allowable livestock. It should be noted that the grazing pressure of each sampling site was determined according to the location of each sampling site in the grazing allotment maps. Finally, it should be added that the total available forage was calculated as follows: total available forage $=$ average forage production in each grazing allotment $\times$ allowable use $\times$ area of each grazing allotment, and the forage demand was calculated as follows: forage demand=livestock weight $\times 2 \%$ of body weight $\times$ grazing period (note: allowable use, livestock weight, and grazing period were about $50 \%, 50 \mathrm{~kg}$, and 120 days, respectively).

\subsection{Statistical analysis}

The data (including plant species and related environmental factors) were analyzed by a series of multivariate techniques such as two-way indicator species analysis (TWINSPAN), detrended correspondence analysis (DCA), principal component analysis (PCA), and canonical correspondence analysis (CCA) using the PC_ORD software version 4.1 (McCune and Mefford, 1999). The floristic data matrix was classified by TWINSPAN. All the default settings in the PC_ORD software were used for TWINSPAN, with except that the pseudo-species cut levels were altered to $0,2,5,7,10,20,40,80$, and 100 . We first applied DCA to find major gradients in the distributions of plant species. Then, based on the gradient lengths of the first two DCA axes, we used PCA to determine the environmental factors that separated the plant groups and to identify the variability of each environmental factor. Finally, we used CCA to interpret the relationship between the species composition and the PCA-selected environmental factors. It should be pointed out that we standardized or normalized all variables (including plant species and related environmental factors) to eliminate the unconformity of the units used in different measurements. Furthermore, we tested the significance of species-environment relationships and the eigenvalues of the CCA axes using Monte Carlo test.

\section{Results}

\subsection{Floristic characteristics}

In total, 75 plant species belonging to 52 genera and 19 families were recorded and identified (Table 1). At the family level, Asteraceae, Papilionaceae, and Lamiaceae were larger families, accounting for $21.05 \%$ (16 species), $18.42 \%$ (14 species), and $9.21 \%$ (6 species) of all identified species, respectively. At the genus level, abundant genera included Astragalus (12 species), Cousinia (4 species), Acanthophyllum (4 species), and Acantholimon (3 species). At the species level, Stipa barbata, Scariola orientalis, and Stachys inflate had higher frequencies (i.e., 95.1\%, $85.4 \%$, and $75.6 \%$, respectively). Artemisia aucheri and Artemisia sieberi, with respective canopy cover of $28.9 \%$ and $17.2 \%$, were present in 20 and 19 sampling sites, respectively. Thus, they were considered as the indicator species in the study area. Furthermore, hemicryptophytes were the dominant life forms (accounting for 50.7\% of all identified species), followed by chamaephytes $(40.0 \%)$, cryptophytes $(5.3 \%)$, and therophytes $(4.0 \%)$.

\subsection{Plant species classification}

Results of TWINSPAN classification for plant species collected at 41 sampling sites are presented in Figure 2. The plant species were classified into 10 main plant groups. And, the indicator species in those groups were as follows: Lunea spinosa in Group 1, Cousinia cungesta in Group 2, 
Table 1 Characteristics of the identified species in the study area

\begin{tabular}{|c|c|c|c|c|c|c|c|c|c|}
\hline Species name & Abbr & Family & $\begin{array}{l}\text { Canopy } \\
\text { cover }(\%)\end{array}$ & $\begin{array}{l}\text { Life } \\
\text { form }\end{array}$ & Species name & Abbr & Family & $\begin{array}{l}\text { Canopy } \\
\text { cover }(\%)\end{array}$ & $\begin{array}{l}\text { Life } \\
\text { form }\end{array}$ \\
\hline $\begin{array}{l}\text { Echinophora } \\
\text { blatvloba }\end{array}$ & Ech-pl & Apiaceae & 0.040 & $\mathrm{He}$ & Phlomis olivieri & Phl-ol & Lamiaceae & 1.090 & $\mathrm{He}$ \\
\hline Eryngium billardieri & Ery-bi & Apiaceae & 0.400 & $\mathrm{He}$ & Salvia macrosiphon & Sal-ma & Lamiaceae & 0.070 & $\mathrm{He}$ \\
\hline Eryngium bungei & Ery-bu & Apiaceae & 0.170 & $\mathrm{He}$ & $\begin{array}{l}\text { Scutellaria } \\
\text { multicaulis }\end{array}$ & Scu-mu & Lamiaceae & 0.010 & $\mathrm{He}$ \\
\hline Ferula ovina & Fer-ov & Apiaceae & 0.510 & $\mathrm{He}$ & Stachys inflata & Sta-in & Lamiaceae & 3.170 & $\mathrm{He}$ \\
\hline Artemisia aucheri & Art-au & Asteraceae & 28.910 & $\mathrm{Ch}$ & Ziziphora tenuior & Ziz-te & Lamiaceae & 0.050 & $\mathrm{Th}$ \\
\hline Artemisia sieberi & Art-si & Asteraceae & 17.210 & $\mathrm{Ch}$ & Eremurus spectabilis & Ere-sp & Liliaceae & 0.030 & $\mathrm{Cr}$ \\
\hline Centaurea albonitens & Cen-al & Asteraceae & 1.160 & $\mathrm{He}$ & Orobanche alba & Oro-al & Orobanchaceae & 0.002 & $\mathrm{Cr}$ \\
\hline Centaurea gaubae & Cen-ga & Asteraceae & 0.510 & $\mathrm{He}$ & Alhagi camelorum & Alh-ca & Papilionaceae & 0.100 & $\mathrm{He}$ \\
\hline Cirsium congestum & $\mathrm{Cir}-\mathrm{CO}$ & Asteraceae & 0.350 & $\mathrm{He}$ & $\begin{array}{l}\text { Astragalus } \\
\text { callistachys }\end{array}$ & Ast-cal & Papilionaceae & 0.060 & $\mathrm{Ch}$ \\
\hline Cousinia bachtiarica & Cou-ba & Asteraceae & 1.410 & $\mathrm{He}$ & $\begin{array}{l}\text { Astragalus } \\
\text { campylathus }\end{array}$ & Ast-cam & Papilionaceae & 0.070 & $\mathrm{Ch}$ \\
\hline Cousinia cungesta & $\mathrm{Cou}-\mathrm{cu}$ & Asteraceae & 1.140 & $\mathrm{He}$ & Astragalus fisheri & Ast-fi & Papilionaceae & 0.030 & $\mathrm{Ch}$ \\
\hline Cousinia lasiolepis & Cen-la & Asteraceae & 0.210 & $\mathrm{He}$ & $\begin{array}{l}\text { Astragalus } \\
\text { alobiflorus }\end{array}$ & Ast-gl & Papilionaceae & 4.510 & $\mathrm{Ch}$ \\
\hline Cousinia piptocephala & Cou-pi & Asteraceae & 0.500 & $\mathrm{He}$ & $\begin{array}{l}\text { Astragalus } \\
\text { alucocanthus }\end{array}$ & Ast-gluc & Papilionaceae & 0.004 & $\mathrm{Ch}$ \\
\hline Echinops elymaticus & Ech-el & Asteraceae & 1.590 & $\mathrm{He}$ & $\begin{array}{l}\text { Astragalus } \\
\text { alumaceus }\end{array}$ & Ast-glum & Papilionaceae & 0.010 & $\mathrm{Ch}$ \\
\hline Echinops robustus & Ech-ro & Asteraceae & 0.020 & $\mathrm{He}$ & $\begin{array}{l}\text { Astragalus } \\
\text { piptocephalus }\end{array}$ & Ast-pi & Papilionaceae & 0.080 & $\mathrm{Ch}$ \\
\hline Hertia angustifolia & Her-an & Asteraceae & 0.720 & $\mathrm{Ch}$ & $\begin{array}{l}\text { Astragalus } \\
\text { podolobus }\end{array}$ & Ast-po & Papilionaceae & 0.790 & $\mathrm{Ch}$ \\
\hline Lunea spinosa & Lun-sp & Asteraceae & 1.190 & $\mathrm{He}$ & $\begin{array}{l}\text { Astragalus } \\
\text { pvcnocephalus }\end{array}$ & Ast-py & Papilionaceae & 1.940 & $\mathrm{Ch}$ \\
\hline $\begin{array}{l}\text { Onopordon } \\
\text { heteracanthum }\end{array}$ & Ono-he & Asteraceae & 0.110 & $\mathrm{He}$ & $\begin{array}{l}\text { Astragalus } \\
\text { schistosus }\end{array}$ & Ast-sch & Papilionaceae & 0.030 & $\mathrm{He}$ \\
\hline Scariola orientalis & Sca-or & Asteraceae & 6.000 & $\mathrm{Ch}$ & $\begin{array}{l}\text { Astragalus } \\
\text { scleroclodus }\end{array}$ & Ast-scl & Papilionaceae & 0.210 & $\mathrm{Ch}$ \\
\hline $\begin{array}{l}\text { Tanacetum } \\
\text { polycephalum }\end{array}$ & Tan-po & Asteraceae & 0.420 & $\mathrm{He}$ & Astragalus verus & Ast-ve & Papilionaceae & 2.610 & $\mathrm{Ch}$ \\
\hline Descurainia sophia & Des-so & Brassicaceae & 0.140 & $\mathrm{Th}$ & Onobrychis cornuta & Ono-co & Papilionaceae & 0.090 & $\mathrm{Ch}$ \\
\hline Lepidium persicum & Lep-pe & Brassicaceae & 0.010 & $\mathrm{He}$ & $\begin{array}{l}\text { Andrachne } \\
\text { telephioides }\end{array}$ & And-te & Phyllanthaceae & 0.140 & $\mathrm{He}$ \\
\hline Matthiola alyssifolia & Mat-ov & Brassicaceae & 0.005 & $\mathrm{He}$ & $\begin{array}{l}\text { Acantholimon } \\
\text { aspadanum }\end{array}$ & Aca-as & Plumbaginaceae & 0.290 & $\mathrm{Ch}$ \\
\hline $\begin{array}{l}\text { Acanthophyllum } \\
\text { crassifolium }\end{array}$ & Aca-cr & Caryophyllaceae & 0.007 & $\mathrm{Ch}$ & $\begin{array}{l}\text { Acantholimon } \\
\text { festocaceum }\end{array}$ & Aca-fe & Plumbaginaceae & 0.200 & $\mathrm{Ch}$ \\
\hline $\begin{array}{l}\text { Acanthophyllum } \\
\text { microcephalum }\end{array}$ & Aca-mi & Caryophyllaceae & 0.080 & $\mathrm{Ch}$ & $\begin{array}{l}\text { Acantholimon } \\
\text { oliaanthum }\end{array}$ & Aca-ol & Plumbaginaceae & 0.660 & $\mathrm{Ch}$ \\
\hline $\begin{array}{l}\text { Acanthophyllum } \\
\text { squarrosum }\end{array}$ & Aca-sq & Caryophyllaceae & 0.370 & $\mathrm{Ch}$ & Boissiera squarrosa & Boi-sq & Poaceae & 0.070 & $\mathrm{Th}$ \\
\hline $\begin{array}{l}\text { Acanthophyllu } \\
\text { spinosum }\end{array}$ & Aca-sp & Caryophyllaceae & 1.440 & $\mathrm{Ch}$ & Bromus tomentellus & Bro-to & Poaceae & 2.170 & $\mathrm{He}$ \\
\hline Dianthus orientalis & Dia-or & Caryophyllaceae & 0.070 & $\mathrm{Ch}$ & Melica persica & Mel-pe & Poaceae & 0.030 & $\mathrm{He}$ \\
\hline Gypsophila virgata & Gyp-vi & Caryophyllaceae & 0.004 & $\mathrm{Ch}$ & $\begin{array}{l}\text { Oryzopsis } \\
\text { holciformis }\end{array}$ & Ory-ho & Poaceae & 0.010 & $\mathrm{He}$ \\
\hline Anabasis aphylla & Ana-ap & Chenopodiaceae & 2.660 & $\mathrm{He}$ & Poa bulbosa & Poa-bu & Poaceae & 0.040 & $\mathrm{Cr}$ \\
\hline Eurotia ceratoides & Eur-ce & Chenopodiaceae & 0.930 & $\mathrm{Ch}$ & Stipa barbata & Sti-ba & Poaceae & 3.120 & $\mathrm{He}$ \\
\hline Kochia prostrate & Koc-pr & Chenopodiaceae & 2.060 & $\mathrm{Ch}$ & Reseda buhseana & Res-bu & Resedaceae & 0.090 & $\mathrm{He}$ \\
\hline Noaea mucronata & Noa-mu & Chenopodiaceae & 4.460 & $\mathrm{Ch}$ & Scrophularia striata & Scr-st & Scrophulariaceae & 0.070 & $\mathrm{Ch}$ \\
\hline $\begin{array}{l}\text { Euphorbia } \\
\text { cheiradenia }\end{array}$ & Eup-ch & Euphorbiaceae & 0.550 & $\mathrm{He}$ & $\begin{array}{l}\text { Verbascum } \\
\text { speciosum }\end{array}$ & Ver-sp & Scrophulariaceae & 0.080 & $\mathrm{He}$ \\
\hline Euphorbia decipiens & Eup-de & Euphorbiaceae & 0.190 & $\mathrm{He}$ & Hyoscyamus nigrum & Hyo-ni & Solanacea & 0.020 & $\mathrm{He}$ \\
\hline Iris songarica & Iri-so & Iridaceae & 1.260 & $\mathrm{Cr}$ & $\begin{array}{l}\text { Dendrostellera } \\
\text { lessertii }\end{array}$ & Den-le & Thymelaeaceae & 0.280 & $\mathrm{Ch}$ \\
\hline Mentha longifolia & Men-lo & Lamiaceae & 0.030 & $\mathrm{He}$ & Peganum harmala & Peg-ha & Zygophyllaceae & 0.880 & $\mathrm{He}$ \\
\hline Nepeta oxyodonta & Nep-ox & Lamiaceae & 0.020 & $\mathrm{He}$ & & & & & \\
\hline
\end{tabular}


Anabasis aphylla in Group 3, Astragalus verus in Group 4, Artemisia sieberi in Group 5, Scariola orientalis in Group 6, Astragalus pycnocephalus in Group 7, Centaurea albonitens in Group 8, Artemisia aucheri and Astragalus globiflorus in Group 9, and Bromus tomentellus and Acantholimon oliganthum in Group 10. As shown in Table 2, characteristics of the 10 plant groups varied significantly.

It should be pointed out that DCA can be used to estimate the magnitudes of changes in species composition along the first two ordination axes, providing gradient length estimations for PCA and CCA ordinations (El-Ghani and Amer, 2003; He et al., 2007; Jeloudar et al., 2010). In this study, the distributions of sampling sites and plant species along the first two DCA axes tended to lend supports to the results of TWINSPAN classification (Fig. 3). Floristic variations along the two DCA axes showed gradient lengths of 3.79 and 2.50 standard-deviation units, respectively. The larger eigenvalue of the first DCA axis (0.799) indicated that this axis encompassed a high proportion of variations in species composition among the sampling sites. If the gradient length of the first DCA axis was between 3 and 4 standard-deviation units, there was no difference of using linear ordination models from using unimodal ordination models (Jongman et al., 1995). Therefore, PCA was used to determine the environmental factors that separated the plant groups and also to identify the variability of each environmental factor. Finally, CCA was used to demonstrate the relationships between species composition and environmental factors.

\subsection{Variations of environmental factors among different plant groups}

Results of PCA ordination are presented in Tables 3 and 4. The eigenvalues of ordination axes showed that the first two PCA ordination axes together accounted for $66.7 \%$ of the total variance (37.5\% for axis 1 and $29.2 \%$ for axis 2 ), indicating that the first two ordination axes could reflect variations in the plant species compositions and the environmental factors.

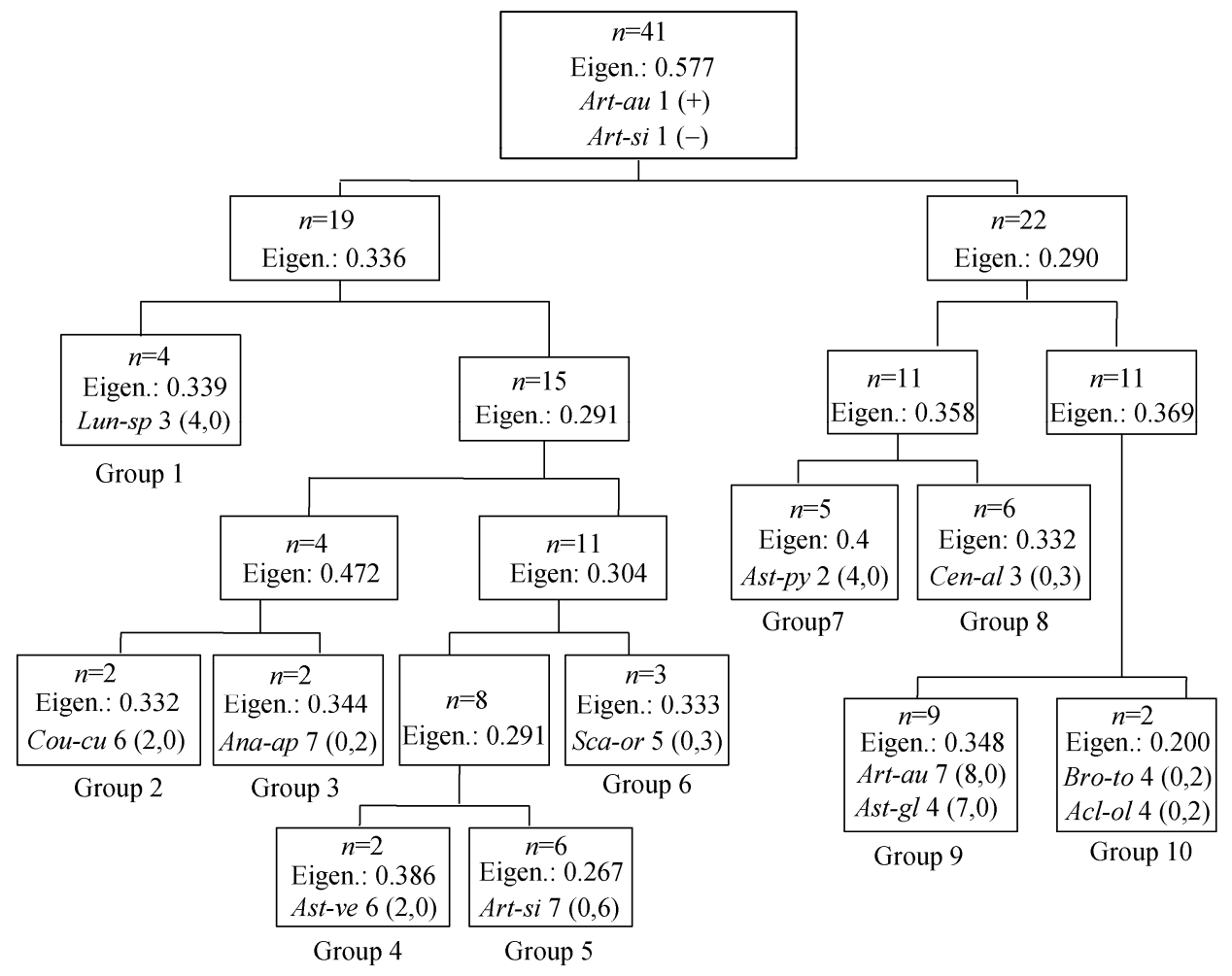

Fig. 2 Dendrogram of TWINSPAN (two-way indicator species analysis) classification for plant species in the study area. Indicator species are shown with pseudo-values. Abbreviations of plant species are shown in Table 1 (note: Eigen.=Eigenvalue). 


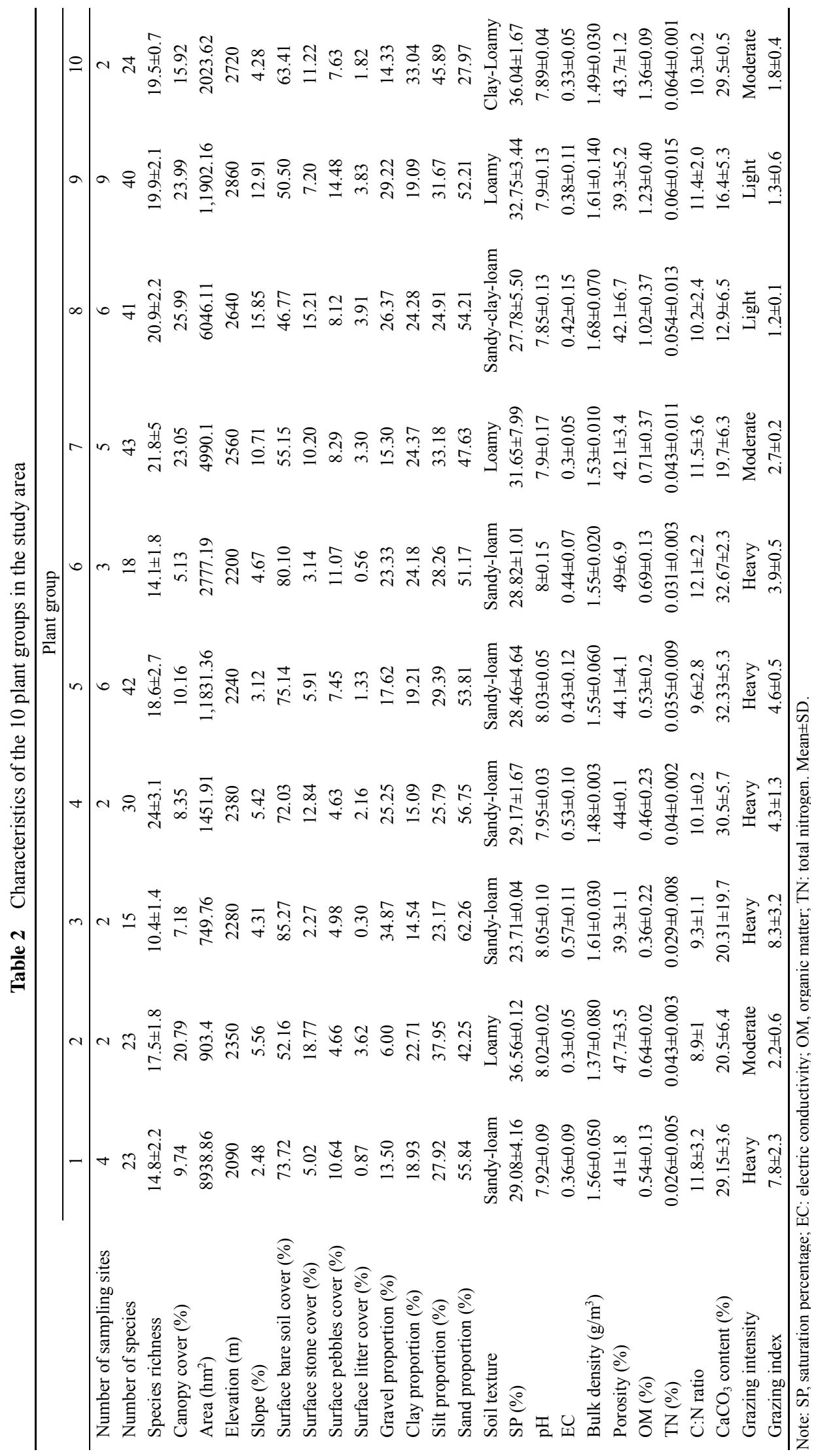




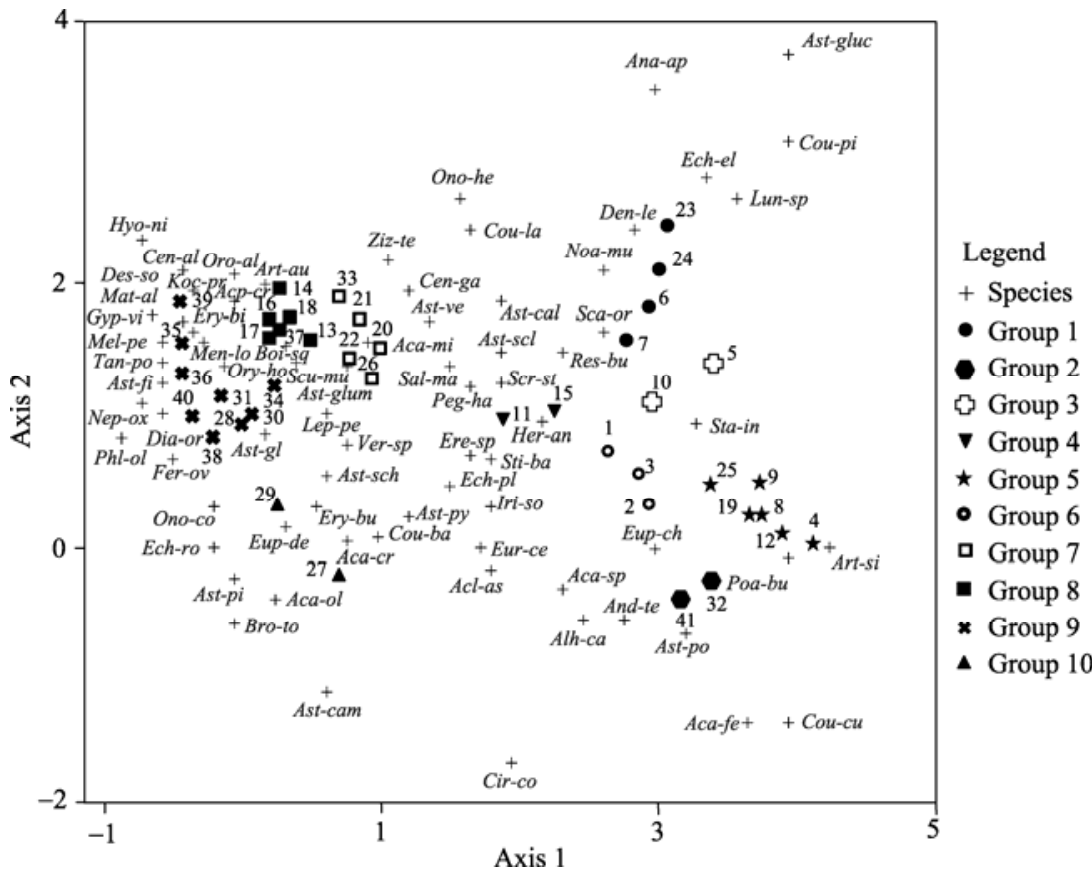

Fig. 3 Ordination diagram of the 41 sampling sites and 75 plant species along the first two DCA (detrended correspondence analysis) ordination axes. Eigenvalues of the first and second DCA axes are 0.799 and 0.334, respectively. The abbreviations of plant species are shown in Table 1.

Table 3 Eigenvalues and variances of the first three PCA (principal component analysis) ordination axes

\begin{tabular}{cccc}
\hline & Axis 1 & Axis 2 & Axis 3 \\
\hline Eigenvalue & 11.7 & 9.24 & 4.33 \\
Percentage of variance (\%) & 37.5 & 29.2 & 12.6 \\
Cumulative percentage of variance (\%) & 37.5 & 66.7 & 79.3 \\
Broken-stick eigenvalue & 4.22 & 3.32 & 2.82 \\
\hline
\end{tabular}

Table 4 Eigenvectors of environmental factors for the first three PCA ordination axes

\begin{tabular}{|c|c|c|c|c|c|c|c|c|c|}
\hline \multirow{2}{*}{ Factor } & \multirow{2}{*}{$\begin{array}{c}\text { Soil } \\
\text { depth } \\
\text { (cm) }\end{array}$} & \multicolumn{3}{|c|}{ Eigenvector } & \multirow{2}{*}{ Factor } & \multirow{2}{*}{$\begin{array}{c}\text { Soil } \\
\text { depth } \\
\text { (cm) }\end{array}$} & \multicolumn{3}{|c|}{ Eigenvector } \\
\hline & & Axis 1 & Axis 2 & Axis 3 & & & Axis 1 & Axis 2 & Axis 3 \\
\hline Elevation & & -0.19 & 0.30 & 0.05 & \multirow{2}{*}{ Silt proportion } & $0-30$ & -0.27 & -0.06 & 0.10 \\
\hline Slop & & -0.06 & 0.24 & -0.11 & & $30-60$ & -0.26 & -0.12 & 0.06 \\
\hline Aspect & & 0.01 & 0.11 & 0.41 & \multirow{2}{*}{ Sand proportion } & $0-30$ & 0.27 & 0.07 & -0.12 \\
\hline Surface stone cover & & -0.12 & 0.11 & -0.26 & & $30-60$ & 0.27 & 0.09 & -0.12 \\
\hline Surface pebble cover & & 0.09 & -0.07 & 0.21 & \multirow{2}{*}{ Clay proportion } & $0-30$ & -0.10 & -0.05 & 0.10 \\
\hline Surface bare soil cover & & 0.16 & -0.22 & 0.16 & & $30-60$ & -0.23 & -0.04 & 0.17 \\
\hline Surface litter cover & & -0.18 & 0.20 & -0.19 & \multirow{2}{*}{$\begin{array}{c}\text { Gravel } \\
\text { proportion }\end{array}$} & $0-30$ & 0.13 & 0.26 & 0.13 \\
\hline \multirow{2}{*}{ SP } & $0-30$ & -0.26 & -0.03 & 0.04 & & $30-60$ & 0.16 & 0.20 & 0.14 \\
\hline & $30-60$ & -0.23 & -0.17 & -0.10 & \multirow{2}{*}{ Porosity } & $0-30$ & 0.00 & -0.01 & -0.01 \\
\hline \multirow{2}{*}{$\mathrm{TN}$} & $0-30$ & -0.21 & 0.16 & 0.12 & & $30-60$ & 0.09 & -0.17 & 0.22 \\
\hline & $30-60$ & -0.23 & 0.16 & 0.10 & \multirow{2}{*}{ Bulk density } & $0-30$ & 0.18 & 0.18 & 0.08 \\
\hline \multirow{2}{*}{$\mathrm{OM}$} & $0-30$ & -0.23 & 0.11 & 0.18 & & $30-60$ & 0.12 & 0.14 & 0.03 \\
\hline & $30-60$ & -0.26 & 0.20 & 0.13 & \multirow{2}{*}{$\mathrm{pH}$} & $0-30$ & -0.09 & -0.12 & -0.09 \\
\hline \multirow{2}{*}{$\mathrm{C}: \mathrm{N}$ ratio } & $0-30$ & -0.09 & -0.06 & 0.09 & & $30-60$ & 0.14 & -0.15 & -0.05 \\
\hline & $30-60$ & 0.09 & 0.08 & 0.11 & \multirow{2}{*}{$\mathrm{EC}$} & $0-30$ & 0.12 & 0.14 & 0.10 \\
\hline \multirow{2}{*}{$\mathrm{CaCO}_{3}$ content } & $0-30$ & 0.05 & -0.28 & 0.17 & & $30-60$ & 0.11 & 0.17 & 0.07 \\
\hline & $30-60$ & 0.06 & -0.25 & -0.25 & Grazing index & & 0.19 & -0.25 & -0.03 \\
\hline
\end{tabular}

Eigenvector of each environmental factor was determined by consideration of the eigenvectors between environmental factors and PCA ordination axes. Table 4 shows that the most significant 
factors influencing the axis 1 were soil saturation percentage, total nitrogen, organic matter, silt proportion, and sand proportion in the two soil layers $(0-30$ and $30-60 \mathrm{~cm})$ and clay proportion in the second soil layer $(30-60 \mathrm{~cm})$. Thus, it can be concluded that this axis (i.e., the first PCA ordination axis) reflected the variations of soil fertility, soil texture, and soil saturation percentage in the study area. Furthermore, the axis 2 had a high correlation with elevation, slope, grazing intensity, surface bare soil cover, surface litter cover, gravel proportion in the first soil layer (0-30 $\mathrm{cm})$ and $\mathrm{CaCO}_{3}$ content in the two soil layers $(0-30$ and 30-60 cm). Therefore, this axis reflected the variations of topography, grazing intensity and $\mathrm{CaCO}_{3}$ content.

Distributions of environmental factors along the two PCA ordination axes and their influences on plant groups are shown in Figure 4. It can be seen that eigenvectors of most environmental factors in the first PCA ordination axis were negative, such as elevation, slope, soil total nitrogen, silt proportion, etc. (Table 2). Group 7 and Group 10 were on the negative side along axis 1, and they had a direct and significant relationship with those environmental factors reflected by the axis 1 (i.e., soil fertility, soil texture, and soil saturation percentage). Soil organic matter content was largest in Group $10(1.36 \% \pm 0.09 \%)$, which was beneficial to the establishment of such species as Bromus tomentellus in the northwestern region of the study area. Being different from Group 7 and Group 10, Group 4 was on the positive side along the axis 1. It had a negative relationship with soil fertility and soil saturation percentage, but a positive relationship with sand proportion in the two soil layers $(0-30$ and $30-60 \mathrm{~cm})$.
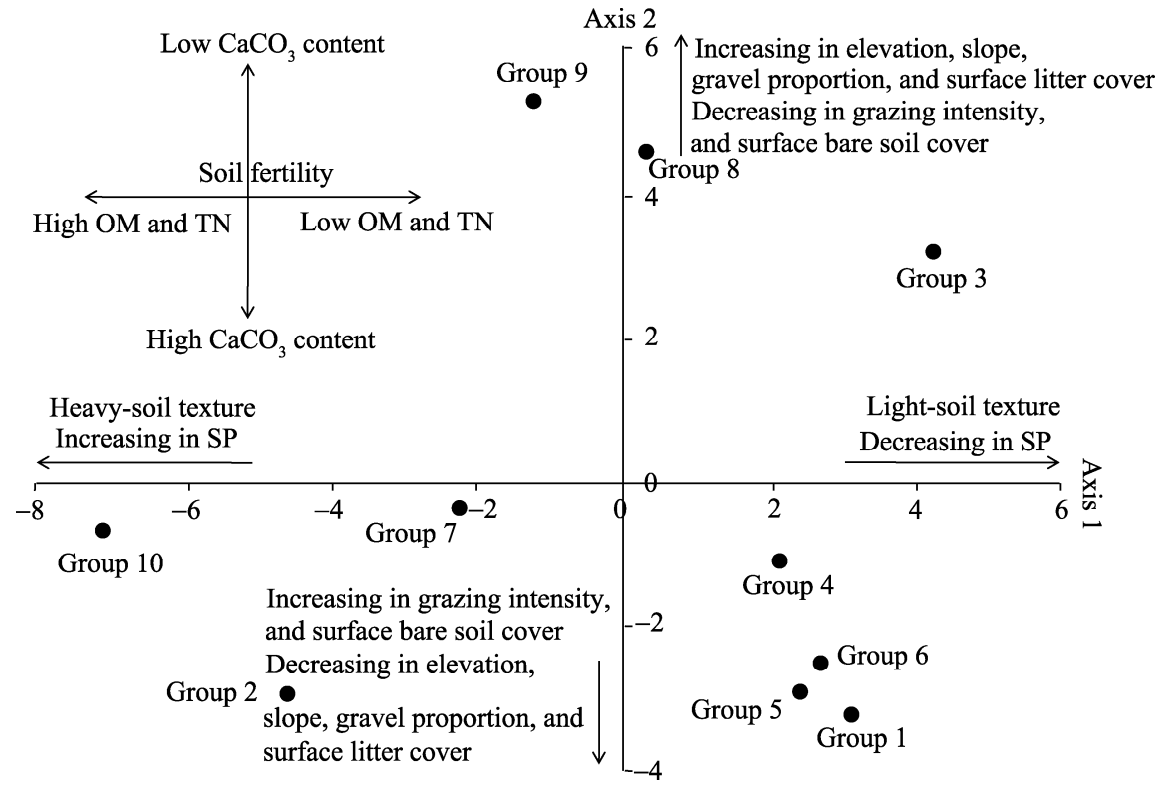

Fig. 4 PCA (principal component analysis) ordination diagram of plant groups and environmental factors. OM, organic matter; TN, total nitrogen; SP, saturation percentage.

In the axis 2 (i.e., the second PCA ordination axis), the eigenvectors of grazing intensity, surface bare soil cover and $\mathrm{CaCO}_{3}$ content were negative, while the eigenvectors of elevation, slope, surface litter cover, and gravel proportion were positive (Table 2). As shown in Figure 4, Group 8 and Group 9 had high positive values along the axis 2 and thus they had a strong relationship with those environmental factors reflected by the axis 2 (i.e., elevation, slope, gravel proportion, and surface litter cover). It should be added that the two groups (Group 8 and Group 9) had a weak relationship with those environmental factors reflected by the axis 1 (i.e., soil fertility, soil texture, and soil saturation percentage). Overall, these two groups appeared in the high-slope regions in the northern and northeastern parts of the study area where $\mathrm{CaCO}_{3}$ content was low (Table 2). Group 1, Group 5, and Group 6 were related to positive values along the axis 1 and to negative values along the axis 2 , implying that the environmental factors influencing them being 
similar. Those three groups showed positive relationships with grazing intensity, surface bare soil cover, and $\mathrm{CaCO}_{3}$ content in the two soil layers $(0-30$ and 30-60 $\mathrm{cm})$ and negative relationships with elevation and slope as well as gravel proportion, organic matter, and saturation percentage in the two soil layers $(0-30$ and $30-60 \mathrm{~cm})$ and clay proportion in the second soil layer $(30-60 \mathrm{~cm})$. Overall, they were located on the lowland plain in the southern and southwestern parts of the study area, and the dominant species there was Artemisia sieberi. Being different from the above-mentioned three groups, Group 3 was on the positive side along the axis 1 and also on the positive side along the axis 2 . It had a positive relationship with gravel proportion and sand proportion, and a negative relationship with soil saturation percentage and clay proportion. Overall, this group was distributed in the lowland plain in the central part of the study area where sand proportion, gravel proportion, and grazing intensity were all rather high (Table 2), and the dominant species there was Anabasis aphylla. Group 2 was on the negative side along the axis 1 and also on the negative side along the axis 2 . It showed a positive relationship with soil saturation percentage and a negative relationship with gravel proportion in the first soil layer (0-30 cm; Table 2). Overall, this group was distributed between the mountain highlands and lowland plains in the eastern part of the study area, and the dominant species there was Cousinia cungesta.

In this study, PCA was also used to identify the variations in environmental factors. The results show that environmental factors such as surface stone cover, surface pebbles cover, carbon to nitrogen ratio, porosity, and bulk density showed rather small variabilities and they were thus ignored in the CCA ordination. In the case of edaphic factors with relatively high variabilities (e.g., soil saturation percentage, total nitrogen, $\mathrm{CaCO}_{3}$ content, $\mathrm{pH}$, organic matter, texture, etc.), due to their relatively equal eigenvectors and similar results in PCA ordination (see Table 4), the average values of them in the first and second soil layers $(0-30$ and $30-60 \mathrm{~cm})$ were used in the CCA ordination with exceptions of gravel proportion in the first soil layer $(0-30 \mathrm{~cm})$ and clay proportion in the second soil layer $(30-60 \mathrm{~cm})$.

\subsection{Relationships between species composition and environmental factors}

The first three CCA ordination axes explained $63.9 \%$ of the total variance (Table 5), indicating that the selected environmental factors were suitable for identifying the influential environmental factors. Intra-set correlations of environmental factors with the first two CCA ordination axes showed that the first CCA ordination axis was significantly correlated with elevation, slope, surface bare soil cover, surface litter cover, gravel proportion, organic matter, total nitrogen, grazing intensity, and $\mathrm{CaCO}_{3}$ content; while the second $\mathrm{CCA}$ ordination axis was significantly correlated with soil texture (clay, silt, and sand proportions) and soil saturation percentage (see Table 6).

Relationships between species composition and environmental factors are shown in Figure 5. It can be seen that plant species as well as plant groups can be classified into five habitats according to their relationships with environmental factors. Plant species such as Artemisia aucheri, Centaurea albonitens, Eryngium billardieri, Astragalus pycnocephalus, Kochia prostrate, Astragalus globiflorus, Tanacetum polycephalum, Phlomis olivieri, and Ferula ovina in Habitat III were significantly and positively correlated with elevation, slope, surface litter cover, and gravel proportion in the first soil layer $(0-30 \mathrm{~cm})$, and were significantly and negatively correlated with $\mathrm{CaCO}_{3}$ content, grazing intensity, and surface bare soil cover. Generally speaking, plant species in Habitat III were distributed in the mountain highlands with light grazing pressure (mean grazing index of 1.5), low $\mathrm{CaCO}_{3}$ content (mean of 16.0\%), high canopy cover (mean of $24.34 \%$ ), and high species richness (mean of 21). In contrast, plant species such as Scariola orientalis, Noaea mucronata, Echinops elymaticus, Stachys inflata, and Astragalus podolobus in Habitat IV were significantly and positively correlated with $\mathrm{CaCO}_{3}$ content, grazing intensity, and surface bare soil cover. Generally speaking, plant species in Habitat IV were distributed in the regions with severe degrees of overgrazing (about 6 times of the carrying capacity), high surface bare soil cover (mean of $77 \%$ ), high $\mathrm{CaCO}_{3}$ content (mean of $34 \%$ ), low canopy cover (mean of 
Hadi KARGAR-CHIGANI et al.: Vegetation composition differentiation and species-environment...

Table 5 CCA ordination results and Monte Carlo test for species-environment relationships

\begin{tabular}{cccc}
\hline & Axis 1 & Axis 2 & Axis 3 \\
\hline Eigenvalue & 0.832 & 0.581 & 0.465 \\
Percentage of variance (\%) & 28.3 & 19.8 & 15.8 \\
Cumulative percentage of variance (\%) & 28.3 & 48.0 & 63.9 \\
Species-environment correlation coefficient & $0.999^{* *}$ & $0.998^{* *}$ & $0.997^{* *}$ \\
\hline
\end{tabular}

Note: ${ }^{*}$ and ${ }^{* *}$ mean significance at $P<0: 05$ and $P<0.01$ levels, respectively. CCA, canonical correspondence analysis

Table 6 Intra-set correlations of environmental factors for the first three CCA ordination axes

\begin{tabular}{cccc}
\hline Factor & Axis 1 & Axis 2 & Axis 3 \\
\hline Elevation & $-0.83^{* *}$ & -0.01 & -0.26 \\
Slop & $-0.56^{*}$ & 0.19 & 0.11 \\
Aspect & -0.22 & -0.12 & $-0.40^{*}$ \\
Surface bare soil cover & $0.58^{*}$ & -0.26 & 0.27 \\
Surface litter cover & $-0.47^{*}$ & 0.18 & -0.12 \\
Gravel proportion & $-0.55^{*}$ & $0.44^{*}$ & -0.21 \\
Clay proportion & 0.17 & $-0.70^{* *}$ & 0.15 \\
Silt proportion & 0.22 & $-0.63^{* *}$ & 0.01 \\
Sand proportion & -0.26 & $0.71^{* *}$ & -0.07 \\
pH & 0.28 & -0.11 & $0.49^{*}$ \\
EC & 0.01 & 0.12 & $-0.29^{*}$ \\
SP & 0.22 & $-0.51^{*}$ & 0.26 \\
OM & $-0.63^{* *}$ & -0.25 & -0.19 \\
TN & $-0.50^{*}$ & -0.27 & -0.27 \\
GaCO content & $0.60^{* *}$ & $-0.47^{*}$ & 0.25 \\
\hline
\end{tabular}

Note: ${ }^{*}$ and ${ }^{* *}$ mean significance at $P<0: 05$ and $P<0.01$ levels.

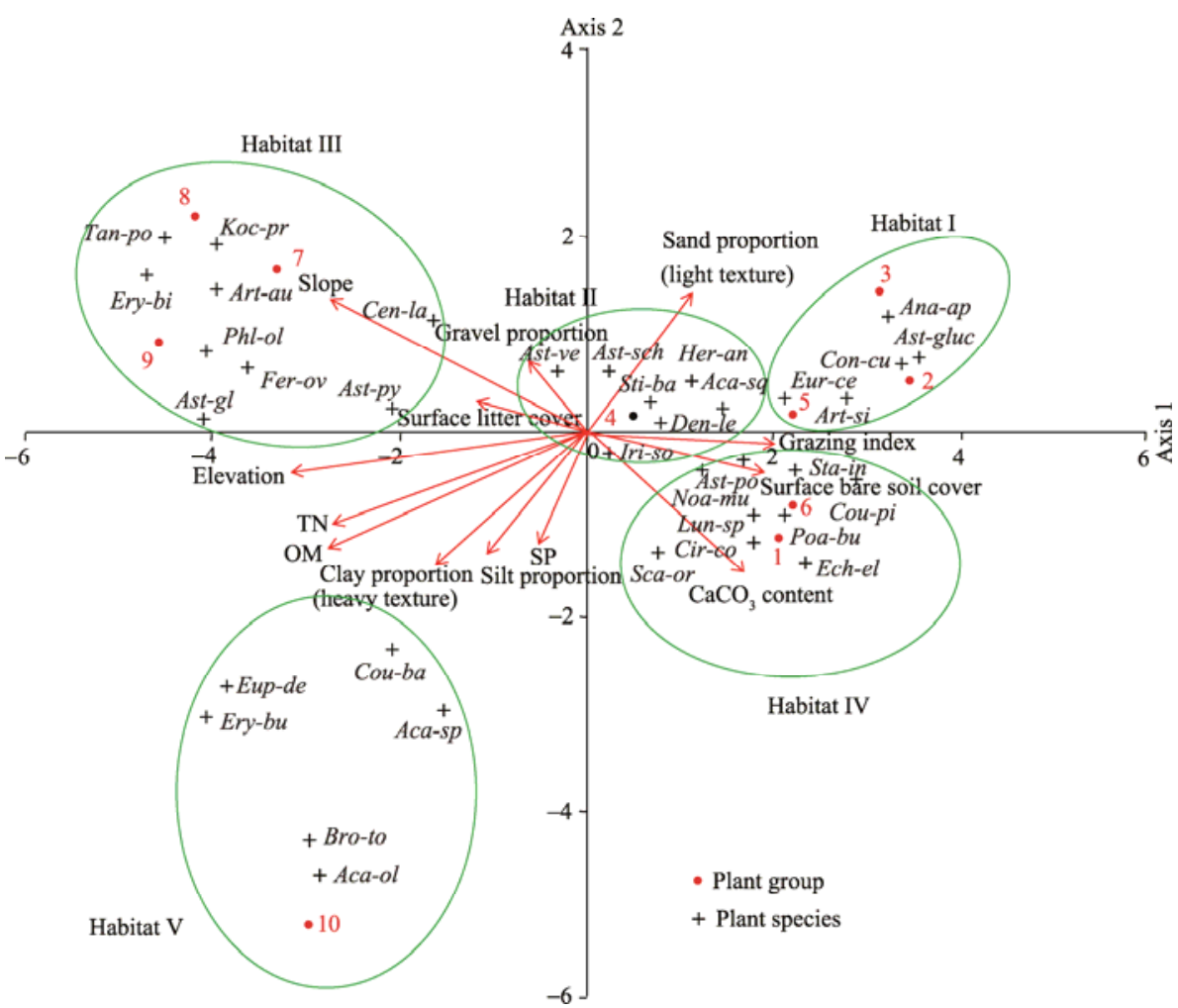

Fig. 5 CCA (canonical correspondence analysis) ordination diagram of plant species, plant groups and environmental factors. Abbreviations of plant species are shown in Table 1. 
7.4\%), and low species richness (mean of 14). In these regions, species richness and canopy cover of the palatable species (i.e., Artemisia sieberi) were lower while species richness and canopy cover of the unpalatable species (e.g., Lunea spinosa, Cousinia piptocephal, Poa bulbosa, and Cirsium congestum were higher.

Habitat V (including Bromus tomentellus, Acantholimon oliganthum, Acantholimon aspadanum, Euphorbia decipiens, Cousinia bachtiarica, and Eryngium bungei) distributed in the lower left quadrant of the diagram was positively correlated with soil organic matter, total nitrogen, silt proportion, clay proportion, and saturation percentage. In contrast, habitat I (including Artemisia sieberi, Cousinia cungesta, Eurotia ceratoides, Anabasis aphylla, and Astragalus glucocanthus) distributed in the upper right quadrant of the diagram was negatively correlated with the above-mentioned factors. Those species were distributed in the lowland plains where the grazing pressure was high (mean grazing index of 5) and soil organic matter was low (mean of $0.51 \%$ ).

Habitat II (including Astragalus verus, Stipa barbata, Astragalus schistosus, Dendrostellera lessertii, and Acanthophyllu spinosum) distributed in the central part of the diagram was closely associated with all environmental factors and the full-range involvement of all environmental factors may be resulted from the fact that this habit occupied the transitional zone between plains and mountains in the study area.

\section{Discussion}

To provide the needed scientific references to species conservation and ecological rehabilitation efforts, the need is pressing to understand the species composition and the relationships to environmental factors at regional scales. In this study area, Artemisia sieberi and Artemisia aucheri were considered as the indicator species. However, distribution of these two species was at two opposite sides. That is, Artemisia sieberi was the dominant species in the low-altitude region, while Artemisia aucheri was the dominant species in the high-altitude region. This finding is in agreement with the result of Jafari et al. (2004) and Sanjerehei et al. (2013).

According to the results of TWINSPAN, plant species in the study area can be classified into 10 plant groups. Spatial distributions of the plant species and the groups were closely related with environmental factors. The first three PCA ordination axes and the first three CCA ordination axes demonstrated similar cumulative percentage of variance $(79.3 \%$ and $63.9 \%$, respectively), indicating that the environmental factors (which were selected by PCA) used in CCA ordination for explaining the species composition are acceptable (McDonald et al., 1996). CCA results showed that the influences of environmental factors (i.e., topography, soil, and grazing intensity) on plant species and groups were mainly expressed by the first two axes. The first CCA ordination axis was significantly correlated with elevation, slope, organic matter, total nitrogen, surface bare soil cover, surface litter cover, gravel proportion, $\mathrm{CaCO}_{3}$ content, and grazing intensity. This axis can be interpreted as a gradient of topography, soil fertility, $\mathrm{CaCO}_{3}$ content, and grazing intensity. That is, they were the dominant environmental factors influencing the distributions of plant species and groups in the study area.

Variations of topographic conditions, especially elevation and slope, were considered as the most effective factors influencing the distributions of plant species and groups in some studies (e.g., Walter, 1985; Enright et al., 2005). For example, Enright et al. (2005) reported that topography influenced the distribution of vegetation more than soil properties and human activities did. For example, elevation, one of topographic parameters, may significantly influence the distributions of plant species and groups through modulating temperature and precipitation (Walter, 1985). Beside topography (elevation and slope), soil fertility (including soil organic matter and total nitrogen) was also found to have significant correlations with distributions of plant species and groups. For example, He et al. (2007) reported that soil fertility, especially organic matter, was the most important factor influencing the vegetation distribution in the Alxa Plateau, China. Moreover, some other studies reported that with increasing elevation, soil organic matter and total nitrogen contents increased, resulting in increases in canopy cover and species 
richness at higher elevations (Salehi et al., 2007; Kargar Chigani et al., 2012). It was early stressed by Plaster (1992) that soil organic matter can be the most important environmental factor controlling the species composition in some cases because it can improve soil aggregate stability, increase soil fertility, enhance plant water availability and facilitate soil mineralization process. Zuo et al. (2014) late demonstrated that soil organic matter and total nitrogen can be equally important to the growth of plant species in other cases.

CCA ordination also showed that $\mathrm{CaCO}_{3}$ content was another important environmental factor. $\mathrm{CaCO}_{3}$ content was negatively correlated with canopy cover in the habitat of Artemisia aucheri, and it was positively correlated with canopy cover in the habit of Artemisia sieberi, being in agreement with the results of Sanjerehei (2012). Generally speaking, soils in arid and semi-arid regions often contain calcium carbonate $\left(\mathrm{CaCO}_{3}\right)$, particularly when the parent materials contain a high level of $\mathrm{CaCO}_{3}$. An appropriate level of $\mathrm{CaCO}_{3}$ content in soils may be beneficial to the growth of plant species because it can adjust soil $\mathrm{pH}$ and increase nutrient absorption. However, an excessive level of $\mathrm{CaCO}_{3}$ content in soils is adverse to the growth of plant species because it can reduce nutrient absorption (Miller and Donahue, 1990).

The rangelands in the northern part of Isfahan Province have recently experienced rather severe degradation and overgrazing has been the primary contributor to the degradation (Amezaga et al., 2004). The documented degradation was well confirmed by our CCA ordination (see Fig. 5). Overgrazing in some parts of the study area, especially in the lowlands, has significantly changed the species composition by reducing species richness (especially the palatable species) and increasing surface bare soil cover (Peterson et al., 2002; Cesa and Paruelo, 2011). Specifically, under overgrazing stress, the domination of palatable species in the study area such as Artemisia sieberi was gradually replaced by unpalatable species such as Scariola orientalis, Lunea spinose, and Noaea mucronata.

The second CCA ordination axis was significantly correlated with soil sand proportion, silt proportion, clay proportion, and saturation percentage. This axis can thus be interpreted as a gradient of soil texture and soil saturation percentage. It should be pointed out that the influences of soil texture on the distribution of plant species have been widely reported in other researches and that soil texture influences plant species distribution primarily through affecting moisture availability, hydraulic conductivity, organic matter, and root distribution (e.g., Jafari et al., 2004; He et al., 2007; Jeloudar et al., 2010).

\section{Conclusions}

This study demonstrated a significant relationship between species composition and environmental factors and the factors included topography (elevation and slope), soil fertility (organic matter and total nitrogen), $\mathrm{CaCO}_{3}$ content, soil texture, and grazing intensity. This study also demonstrated that the complex relationships between species composition and environmental factors can be revealed using a series of classification and ordination techniques (including TWINSPAN, DCA, PCA, and CCA). In this study, TWINSPAN was used to classify the sampling sites and plant species and to identify the indicator species. DCA, as a preliminary analysis, was used to estimate the magnitude of changes in species composition along the first ordination axis and the estimated magnitude can then provide gradient length estimations in PCA and CCA ordinations. This study also showed that linear models (e.g., PCA) could be used to identify the environmental factors influencing the separation of plant groups and to determine the variability of each environmental factor and that unimodal models (e.g., CCA) could be used to demonstrate the relationship between species composition and environmental factors. Human activity, especially overgrazing, is viewed as a major cause of rangeland deterioration in the study area. Therefore, sustainable rangeland management approaches such as prolonged enclosure and grazing prohibition should be adopted to reduce grazing intensity and to protect rangelands. Finally, it is our hope that this study may provide the needed scientific references to species conservation and ecological rehabilitation efforts for the study area and also for other similar areas. 


\section{References}

Amezaga I, Mendarte S, Albizu I, et al. 2004. Grazing intensity, aspect, and slope effects on limestone grassland structure. Journal of Range Management, 57(6): 606-612.

Bai Y G, Abouguendia Z, Redmann R E. 2001. Relationship between plant species diversity and grassland condition. Journal of Range Management, 54(2): 177-183.

Berigari M S, Al-Any F M S. 1994. Gypsum determination in soils by conversion to water-soluble sodium sulfate. Soil Science Society of America Journal, 58(6): 1624-1627.

Black C A. 1965. Methods of soil analysis. American Society of Agronomy, 2: 771-1572.

Bouyoucos G J. 1962. Hydrometer method improved for making particle size analyses of soils. Agronomy Journal, 54(5): 464-465.

Bremner J M, Mulvaney C S. 1982. Nitrogen-total. In: Page A L. Methods of Soil Analysis, Part 2. Madison: American Society of Agronomy and Soil Science Society of America, 595-624.

Cesa A, Paruelo J M. 2011. Changes in vegetation structure induced by domestic grazing in Patagonia (Southern Argentina). Journal of Arid Environments, 75(11): 1129-1135.

Corney P M, Le Duc M G, Smart S M, et al. 2006. Relationships between the species composition of forest field-layer vegetation and environmental drivers, assessed using a national scale survey. Journal of Ecology, 94(2): 383-401.

El-Ghani M M A, Amer W M. 2003. Soil-vegetation relationships in a coastal desert plain of southern Sinai, Egypt. Journal of Arid Environments, 55(4): 607-628.

Enright N J, Miller B P, Akhter R. 2005. Desert vegetation and vegetation-environment relationships in Kirthar National Park, Sindh, Pakistan. Journal of Arid Environments, 61(3): 397-418.

Escudero A, Iriondo J M, Olano J M. 2000. Factors affecting establishment of a gypsophyte: the case of Lepidium subulatum (Brassicaceae). American Journal of Botany, 87(6): 861-871.

He M Z, Zheng J G, Li X R, et al. 2007. Environmental factors affecting vegetation composition in the Alxa Plateau, China. Journal of Arid Environments, 69(3): 473-489.

Hill M O, Gauch Jr H G. 1980. Detrended correspondence analysis: an improved ordination technique. Vegetatio, 42(1): 47-58.

Holechek J L, Pieper R D, Herbel C H. 1998. Range Management: Principles and Practices (3 ${ }^{\text {rd }}$ ed.). Englewood Cliffs, New Jersey: Prentice-Hall, Inc., 189-210.

Jafari M, Chahouki M A Z, Tavili A, et al. 2004. Effective environmental factors in the distribution of vegetation types in poshtkouh rangelands of Yazd province (Iran). Journal of Arid Environments, 56(4): 627-641.

Jeloudar Z J, Arzani H, Jafari M, et al. 2010. Vegetation community in relation to the soil characteristics of Rineh rangeland, Iran. Caspian Journal of Environmental Sciences, 8(2): 141-150.

Jenny H. 1980. The Soil Resource: Origin and Behavior. New York: Springer-Verlag, 279-286.

Jongman R H G, Ter Braak C J F, van Tongeren O F R. 1995. Data Analysis in Community and Landscape Ecology. Cambridge, UK: Cambridge University Press, 153-156.

Kargar Chigani H, Khajeddin S J, Karimzadeh H R. 2012. Soil-vegetation relationships of three arid land plant species and their use in rehabilitating degraded sites. Land Degradation \& Development, 23(1): 92-101.

Koull N, Chehma A. 2015. Soil-vegetation relationships of saline wetlands in north east of Algerian Sahara. Arid Land Research and Management, 29(1): 72-84.

Koull N, Chehma A. 2016. Soil characteristics and plant distribution in saline wetlands of Oued Righ, northeastern Algeria. Journal of Arid Land, 8(6): 948-959.

Ludwig J A, Reynolds J F. 1988. Statistical Ecology: A Primer on Methods and Computing. New York: Wiley, 337.

McCune B, Mefford M J. 1999. PC-ORD Multivariate Analysis of Ecological Data User's Guide Version 4. Gleneden Beach, Oregon, USA: MjM Software Design.

McDonald D J, Cowling R M, Boucher C. 1996. Vegetation-environment relationships on a species-rich coastal mountain range in the fynbos biome (South Africa). Vegetatio, 123(2): 165-182.

Miller R W, Donahue R L. 1990. Soils: An Introduction to Soils and Plant Growth. Englewood Cliffs, NJ, USA: Prentice Hall, 768.

Mueller-Dombois D, Ellenberg H. 1974. Aims and Methods of Vegetation Ecology. New York: John Wiley and Sons, 36-40.

Nimis P L. 1985. Structure and floristic composition of a high arctic tundra: Ny-Ålesund (Svalbard Archipelago). Inter-Nord, 17: 47-58.

Peterson D L, Price K P, Martinko E A. 2002. Investigating grazing intensity and range condition of grasslands in northeastern 
Kansas using Landsat thematic mapper data. Geocarto International, 17(4): 15-26.

Plaster E J. 1992. Soil Science and Management (2 $2^{\text {nd }}$ ed.). New York: Delmar Publishers Inc., 514.

Salehi A, Amiri G Z. 2005. Study of physical and chemical soil properties variations using principal component analysis method in the forest, North of Iran. Caspian Journal of Environmental Sciences, 3(2): 131-137.

Salehi A, Amiri G Z, Burslem D F R P, et al. 2007. Relationships between tree species composition, soil properties and topographic factors in a temperate deciduous forest in northern Iran. Asian Journal of Plant Sciences, 6(3): 455-462.

Sang W G. 2009. Plant diversity patterns and their relationships with soil and climatic factors along an altitudinal gradient in the middle Tianshan Mountain area, Xinjiang, China. Ecological Research, 24(2): 303-314.

Sanjerehei M M. 2012. Soil-vegetation relationships in arid rangelands (case study: Nodushan rangelands of Yazd, Iran). World Academy of Science, Engineering and Technology, 6(7): 999-1004.

Sanjerehei M M, Jafari M, Mataji A, et al. 2013. Influence of environmental factors on distribution of plant species in Nodushan rangelands of Yazd province (Iran). Desert, 18: 19-26.

Van de Ven C M, Weiss S B, Ernst W G. 2007. Plant species distributions under present conditions and forecasted for warmer climates in an arid mountain range. Earth Interactions, 11(9): 1-9.

Van Dyne G M, Vogel W G, Fisser H G. 1963. Influence of small plot size and shape on range herbage production estimates. Ecology, 44(4): 746-759.

Villers-Ruiz L, Trejo-Vázquez I, López-Blanco J. 2003. Dry vegetation in relation to the physical environment in the Baja California Peninsula, Mexico. Journal of Vegetation Science, 14(4): 517-524.

Walter H. 1985. Vegetation of the Earth and Ecological Systems of the Geobiosphere ( $3^{\text {rd }}$ ed.). Berlin-Heidelberg: Springer, 320.

Xu Y J, Chen Y N, Li W H, et al. 2011. Distribution pattern of plant species diversity in the mountainous region of Ili River Valley, Xinjiang. Environmental Monitoring and Assessment, 177(1-4): 681-694.

Zuo X A, Wang S K, Zhao X Y, et al. 2014. Scale dependence of plant species richness and vegetation-environment relationship along a gradient of dune stabilization in Horqin Sandy Land, Northern China. Journal of Arid Land, 6(3): 334-342. 